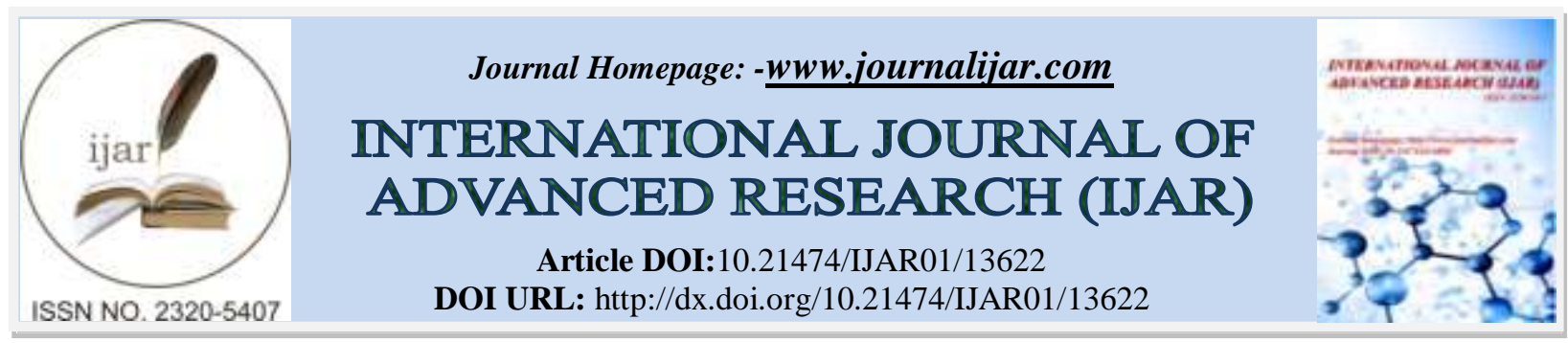

RESEARCH ARTICLE

\title{
EFFECT OF UTILIZING E-LEARNING AS A LEARNING MEDIA AND THE LEVEL OF DIGITAL LITERATURE ON STUDENT LEARNING OUTCOMES IN PRACTICUM COURSES
}

\author{
Gatot Susilo $^{1}$, Sukris Sutiyatno ${ }^{2}$ and Bambang Dewantoro ${ }^{3}$ \\ 1. Lecture, Information Management, STMIK Bina Patria, Magelang. \\ 2. Lecture, Information System, STMIK Bina Patria, Magelang. \\ 3. Lecture, Information Management, AMIK Jakarta Technology Cipta, Semarang.
}

\section{Manuscript Info}

Manuscript History

Received: 31 August 2021

Final Accepted: 30 September 2021

Published: October 2021

\section{Key words:-}

Utilization of E-Learning, Digital Literacy, Student Learning Outcomes, Practicum Courses

\begin{abstract}
The purpose of this study was to investigate the effect of using elearning as a learning medium and the level of digital literacy on student learning outcomes in practicum courses. The research was conducted with a quantitative approach with a survey method. The population in this study were STMIK Bina Patria students. Data collection techniques were carried out by giving questionnaires to respondents. The results showed that the use of e-learning as a learning medium and the level of digital literacy had a significant effect on student learning outcomes for practicum courses, namely the variable utilization of e-learning had a significance value of 0.000 (p-value $<0.05$ ) and the variable digital literacy had a significant value. significance value of 0.035 ( $\mathrm{p}$-value $<0.05$ ). The impact of this research can be a means of alternative solution for lecturer to teach practicum courses and improve the outcome of students' learning.
\end{abstract}

Copy Right, IJAR, 2021,. All rights reserved.

\section{Introduction:-}

The development of information and communication technology, especially the internet, currently has a huge impact on human life. The significance and use of information technology (IT) in every aspect of life and its increasing recognition in the education sector can be an undeniable reality in the contemporary era of the scientific age (Chandio, et. al, 2018; Vitoria, et. al, 2018). The concept of learning by utilizing information and communication technology is called e-Learning. E-Learning is a form of information technology that is applied in the field of education in the form of a virtual world. The term E-Learning is more accurately intended as an effort to make a transformation of the learning process in schools or colleges into digital form which is bridged by internet technology (Munir, 2009). E-learning encircles the varieties of concepts to include online learning, digital learning, virtual learning, distance learning, mobile learning, and computer-assisted instruction, electronic teaching (eteaching), mediated learning, and simulation-based learning as these all are based on the digital learning ecosystem (Frehywot, et.al., 2013). E-Learning has an influence on the evolution of the traditional (conventional) learning process into digital form. E-Learning provides many web-based platforms.

In addition to having an impact on the learning process, the internet also affects many other people's lives, including literacy culture. Literacy activities have transformed into digital literacy. In addition to learning motivation, digital literacy skills are considered to be one of the factors that affect the results in the teaching and learning process. ICT encourages students to improve their literacy and numeracy skills and helps to recognize their existing abilities. It 
also helps with both independent and collaborative learning experiences as learners identify areas where they need assistance and support. In the same vein, learners can complete their education from location as long as they have access to the ICT resource (Amosa, Ogunlade, Obielodan, \& Nasiru, 2017).

The selection of the right learning media can have a good impact on increasing student motivation and literacy. Internet-based learning media (e-Learning) is the right choice at this time. E-Learning helps students to learn more actively and independently. Students can also easily get the information they need when doing assignments and others. The ease of obtaining information is expected to have a positive impact on the results of the student learning process.

Currently, STMIK Bina Patria has 3 study programs, namely: Informatics Engineering (S1), Information Systems (S1), and Information Management (D3). The current Covid-19 pandemic forces all conventional/face-to-face learning at STMIK Bina Patria to switch to online learning, one of which is using e-learning. The success of this learning is influenced by many factors, including the ability of lecturers and students to carry out online learning. The creativity of lecturers in delivering material and the level of student literacy in finding sources of information on the internet also play a very important role. In addition, online learning also has limitations as well. At STMIK Bina Patria, the limited range of internet connections is one of the limitations felt by students. This is because STMIK Bina Patria students come from various regions with different geographical structures. For students who live in the city, internet connection is never a problem. However, for students who come from villages with mountainous geographic areas, internet connection is a major problem.

Based on the description above, the researcher deems it necessary to conduct this research, to investigate the effect of using e-Learning as a learning medium and literacy level on student learning outcomes in practicum courses.

\section{Literature Review:- e-Learning}

Internet facilities allow for use of mechanisms to record information, for example, magnetic disk, tape, optical disc CD, DVD, flash memory drive and paper record. It also includes broadcasting streams such as radio, television, and technology for communication through voice and sound or image, microphone, camera, loudspeaker, telephone or cellular phone. It involves a wide variety of computing hardware, PCs, server mainframe and network storage (Wima \& Lawler, 2014). ICT present opportunities for access to large quantity of information, the size of which goes beyond anyone's imagination., through the use of search engines, like Google, Bing and Yahoo among others (Gavali, 2015). The adoption of e-learning is based on the low delivery cost as once learning stuff is to be produced and uploaded online which escapes away from the expiry date and can be utilized across the world (Allen, 2011). Elearning allows learners to provide them easy accessibility to the material as they require to their study at their favored rapidity except for the stress of missing important information (Roy \&Raymond, 2005).

Henderson in Horton (2003) explains that e-learning is web-based learning that can be accessed from the internet. The application of e-learning in education requires qualified resources, especially human resources so that the implementation of e-learning requires computer literacy for educators and students. Computer literacy is a term that is often used to describe the basic knowledge that laypeople need to know about computers. The concept of computer literacy is more related to the practical aspects of using computers, not the design and development of the computer itself (Murtiyasa, 2006).

Yusuf (2005) confirmed that no country can claim to be educationally advanced unless it embraces technology for its educational activities. ICT as tools within the school environment include use for school administration and management; teaching and learning of ICT related skills to enhance class work presentation; teaching/learning repetitive tasks; teaching/learning intellectual thinking and problem solving skills; stimulating creativity and imagination; for research by teachers and students, and as communication tool by teachers and students (Collis \& Moonen, 2001; Derbyshire, 2003).

The purpose of using e-Learning in the learning system is to expand access to education for the wider community, as well as to improve the quality of learning. The utilization of web e-Learning will improve learning outcomes indirectly. E-Learning has a positive and significant effect on the quality of student learning. The influence is in a strong category. The more intensively e-learning is used, the quality of student learning will also increase (Suharyanto \& Mailangkay, 2016). 
Learning methods using electronics or called e-learning are learning methods that require variety and readiness from many parties. E-learning methods need to be prepared before starting lectures regarding learning design, materials, and forms of discussions and assignments given to students. In this way, the quality of students will be created by the competencies expected by lecturers and institutions. The quality of the implementation of e-learning learning is not influenced by the time students are exposed to the internet, the content provided during e-learning learning, and the facilities used by students such as computers and the internet that can support students doing e-learning (Sianturi \& Lisum, 2018).

\section{Digital Literacy}

In today's technological developments, literacy has become a part of human life. Literacy is the language ability possessed by a person in communicating 'reading, speaking, listening and writing' in different ways according to their goals (Sulzby \& Teale, 1986).

Digital literacy is the ability to search for, understand and use information in various forms that come from a very wide variety of sources obtained using computer media. Digital literacy is very helpful for students in dealing with information that comes from various digital sources which will continue to grow as a result of technological developments.

Good digital literacy skills are needed by students and lecturers in the campus environment. It is intended that the academic community has a critical nature in responding to information.

\section{Research Method:-}

This study uses a quantitative approach with a survey method which aims to determine the effect of the use of eLearning and the level of digital literacy on student learning outcomes in practicum courses. Data was collected using a questionnaire about things that students know by using a Likert scale and documentation in the form of notes, material activity logs, and so on. The population in this study were students of the Informatics Management, Information Systems, and Informatics Engineering study program from STMIK Bina Patria in Central JavaIndonesia. From the existing population, the number of samples taken was 14 students of the Informatics Management study program, 33 students of the Information Systems study program, and 29 students of the Informatics Engineering study program. Data were analyzed by means of regression analysis and processed using SPSS version 23.

\section{Result And Discussions:-}

Table 1:- One-Sample Kolmogorov-Smirnov Test.

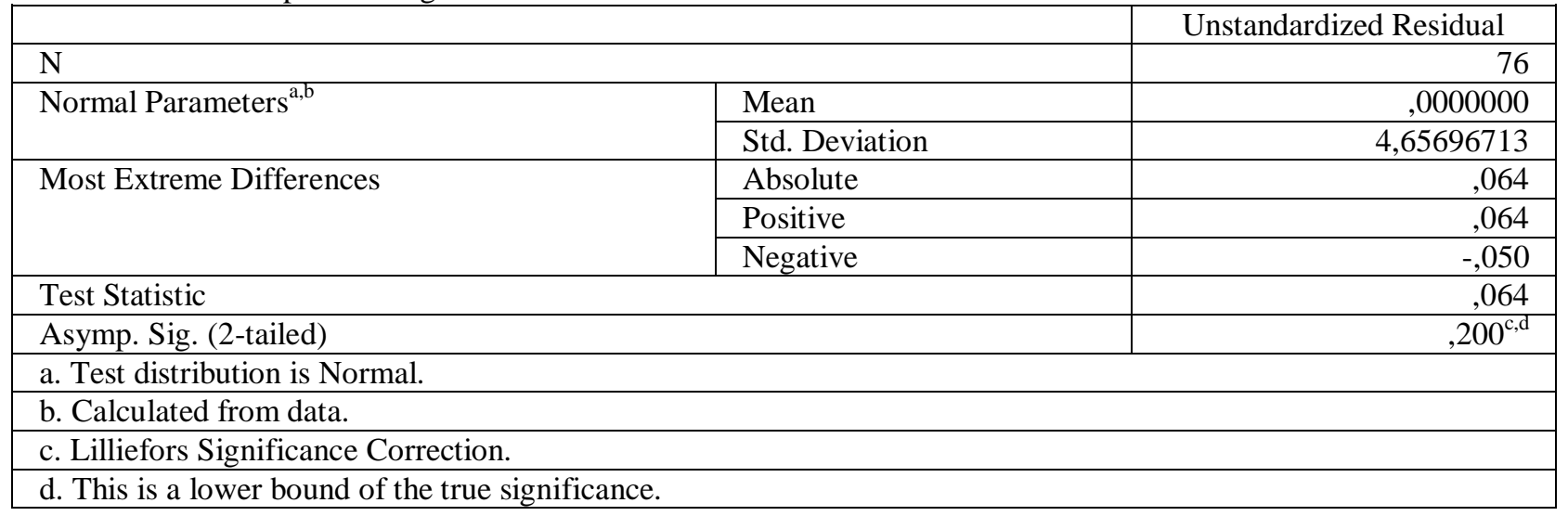

In the normality test (Table 1) the Asymp value. Sig. (2-tailed) is normally distributed because of the Asymp value. Sig. (2-tailed) of $0.200>0.05$. 
Normal P-P Plot of Regression Standardized Residual

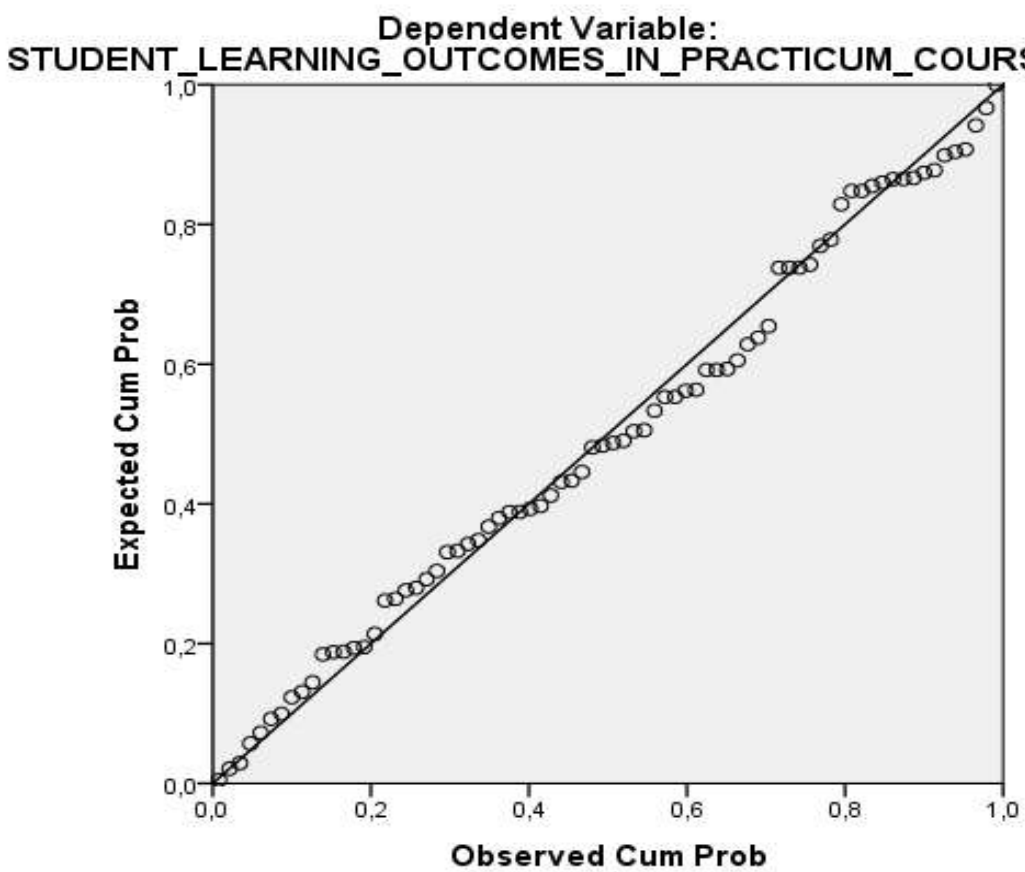

Figure 1:- Normality Test Results.

In Figure 1, the normal plot shows the dots spread around the diagonal line and follow the direction of the diagonal line. By looking at the appearance of the normal plot image, it can be concluded that the normal plot image provides a normal distribution pattern.

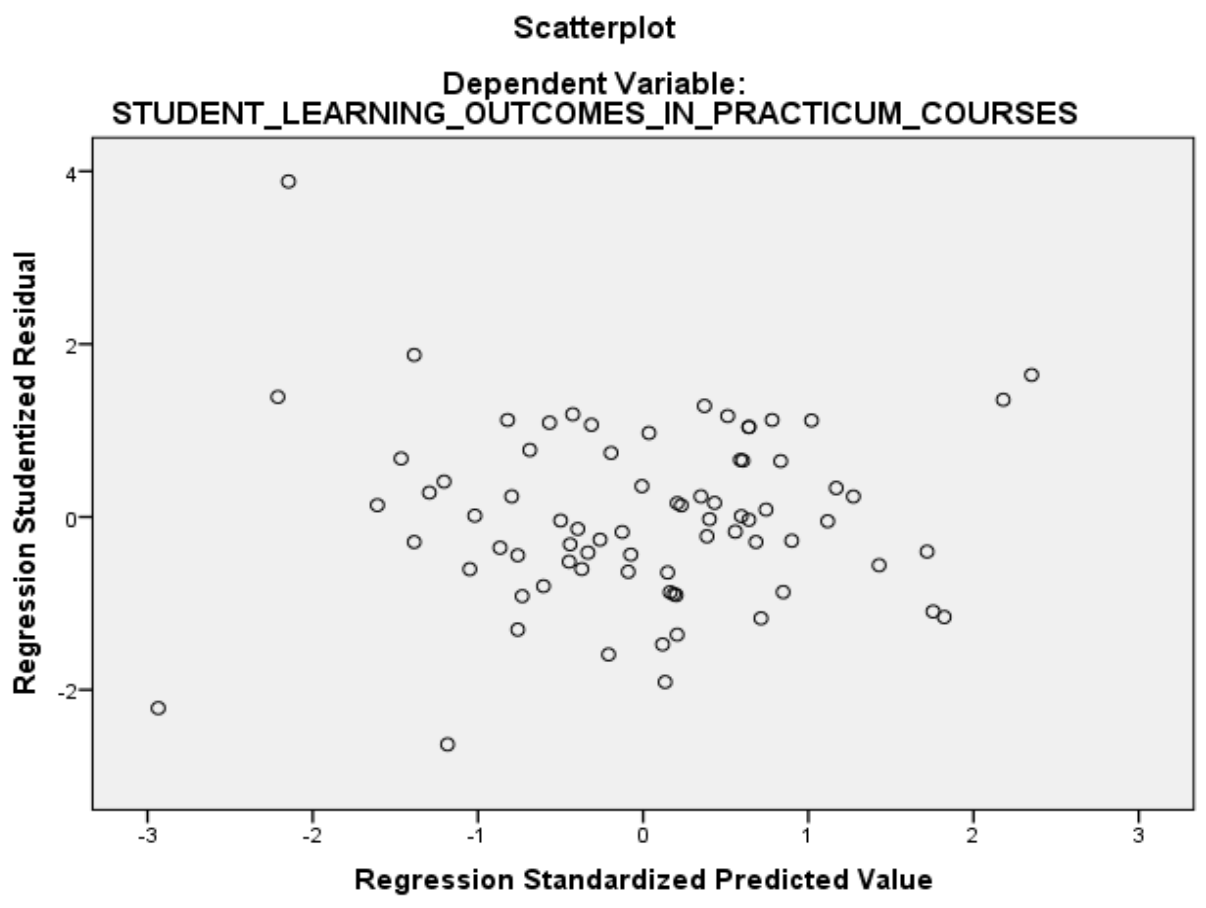

Figure 2:- Heteroskedastisitas. 
The heteroscedasticity test (figure 2) shows that there is no clear pattern, and the points spread above and below the number 0 on the $\mathrm{Y}$ axis, so it can be concluded that there is no heteroscedasticity.

Table 2:- Coefficients ${ }^{\mathrm{a}}$

\begin{tabular}{|c|c|c|c|c|c|c|c|c|}
\hline \multirow{2}{*}{\multicolumn{2}{|c|}{ Model }} & \multicolumn{2}{|c|}{$\begin{array}{c}\text { Unstandardized } \\
\text { Coefficients }\end{array}$} & \multirow{2}{*}{$\begin{array}{c}\begin{array}{c}\text { Standardiz } \\
\text { ed } \\
\text { Coefficien } \\
\text { ts }\end{array} \\
\text { Beta }\end{array}$} & \multirow[t]{2}{*}{$\mathrm{t}$} & \multirow[t]{2}{*}{ Sig. } & \multicolumn{2}{|c|}{$\begin{array}{l}\text { Collinearity } \\
\text { Statistics }\end{array}$} \\
\hline & & B & $\begin{array}{l}\text { Std. } \\
\text { Error }\end{array}$ & & & & $\begin{array}{c}\text { Tolera } \\
\text { nce }\end{array}$ & VIF \\
\hline \multirow[t]{3}{*}{1} & (Constant) & 5,381 & 4,470 & & 1,204 & 233 & & \\
\hline & UTILIZING_ELEARNING &, 518 &, 076 & ,605 & 6,811 &, 000 & ,926 & 1,080 \\
\hline & DIGITAL_LITERATURE & ,226 &, 105 &, 191 & 2,150 & 035 & ,926 & 1,080 \\
\hline
\end{tabular}

The multicollinearity test (Table 2) produces VIF and tolerance values for each variable using e-learning and digital literacy. Tolerance value for all independent variables $>0.10$ and VIF value $<10$. Based on these results, it can be concluded that the regression model used is free from multicollinearity between independent variables.

Table 3:- Model Summary ${ }^{\mathrm{b}}$

\begin{tabular}{|c|c|c|c|c|c|}
\hline Model & $\mathrm{R}$ & R Square & Adjusted R Square & $\begin{array}{l}\text { Std. Error of the } \\
\text { Estimate }\end{array}$ & Durbin-Watson \\
\hline 1 &, $683^{\mathrm{a}}$ & ,466 & ,451 & 4,720 & 1,880 \\
\hline
\end{tabular}

Based on R Square which has a value of $46.6 \%$, this means that the R square variable can explain $46.6 \%$, while the remaining $53.4 \%$ is explained by other variables not included in this study.

Table 4:- ANOVA ${ }^{\mathrm{a}}$

\begin{tabular}{|l|l|r|r|r|r|c|}
\hline Model & Sum of Squares & df & Mean Square & F & Sig. \\
\hline \multirow{3}{*}{1} & Regression & 1419,133 & 2 & 709,567 & 31,846 &, $000^{\mathrm{b}}$ \\
\cline { 2 - 7 } & Residual & 1626,551 & 73 & 22,282 & & \\
\cline { 2 - 7 } & Total & 3045,684 & 75 & & \\
\hline
\end{tabular}

Table 5:- Coefficients ${ }^{\mathrm{a}}$

\begin{tabular}{|c|c|c|c|c|c|c|}
\hline \multicolumn{2}{|c|}{ Model } & \multicolumn{2}{|c|}{ Unstandardized Coefficients } & \multirow{2}{*}{$\begin{array}{c}\text { Standardized } \\
\text { Coefficients } \\
\text { Beta }\end{array}$} & \multirow[t]{2}{*}{$\mathrm{t}$} & \multirow[t]{2}{*}{ Sig. } \\
\hline & & $\mathrm{B}$ & Std. Error & & & \\
\hline \multirow[t]{3}{*}{1} & (Constant) & 5,381 & 4,470 & & 1,204 & ,233 \\
\hline & UTILIZING_ELEARNING &, 518 &, 076 & ,605 & 6,811 & ,000 \\
\hline & DIGITAL_LITERATURE & 226 &, 105 & 191 & 2,150 &, 035 \\
\hline
\end{tabular}

Based on table 5, a statistical t-test was conducted to find out how much influence the use of e-learning and digital literacy had on student learning outcomes for practicum courses as the dependent variable. The basis for the decision taken is to see a significant level of less than $0.05(5 \%)$.

\section{Discussion:-}

Based on table 4, the results of the significance test of the independent variables jointly have a significant effect on the dependent variable. This is indicated by the values $\mathrm{df} 1=2$ and $\mathrm{df} 2=73$. In addition, the calculated $\mathrm{F}$ value $(31.846)>$ F table (3.12), so it can be concluded that the independent variables together have a positive influence on the dependent variable. 
The variable of e-learning utilization has a significance value of 0.000 which is smaller than 0.05 which indicates that there is a significant effect between the use of e-learning on student learning outcomes for practical courses. The results of this study contradict the research conducted by Islamiyah \& Widayanti (2016), which concludes that the implementation of learning using website-based e-learning is less effective in improving student learning outcomes at STMIK Asia Malang.

However, the results of this study are compliant with the research of Suharyanto \& Mailangkay (2016) which states that the use of the e-Learning web will improve learning outcomes indirectly. E-Learning has a positive and significant effect on the quality of student learning. The more intensively e-learning is used, the quality of student learning will also increase. In addition, the results of this study are also in line with research conducted by Pujiastutik (2019) which discusses the effectiveness of the use of web-based e-learning learning media for the Learning Learning 1 course on student learning outcomes. biology class of 2017 can improve. This can be seen from the percentage of students' completeness in the first cycle of $77 \%$ with complete criteria and $92 \%$ in cycle II with very complete criteria. So that these results have reached the expected learning completeness which is 75 . Student responses to the application of web-based e-learning learning media received positive responses from students, where the average percentage was $76 \%$.

This finding is in line with the research conducted by Suwastika (2018) on the effect of e-learning on student learning motivation at STIKOM Bali, it was concluded that based on the results of hypothesis testing with H1 hypothesis regression with a significance value of 0.000 and at count of 4.015 proved so that it was concluded according to students. STIKOM Bali, e-learning affects students' learning motivation.

In the use of e-learning, there are still obstacles that need to be improved, so that the impact on student learning outcomes in practicum courses can be further enhanced. This is by research conducted by La Ucu, et. al (2018) in the analysis of the use of e-learning for the learning process at De La Salle University, Nusantara University, and STMIK Parna Raya, it was concluded that e-learning and conventional learning in the three universities were effective, so that in their application the supervision was further enhanced in learning one of them is by forming face-to-face (conventional) e-learning classes that can be used to discuss various existing obstacles that cannot be resolved in the e-learning group.

In this study, the digital literacy variable has a significance value of 0.035 which is also smaller than 0.05 . This means that the variable level of digital literacy also has a significant influence on student learning outcomes for practicum courses. However, these results contradict the research conducted by Effendi, Bustanur \& Mailani (2019) which revealed that there was no effect of digital media literacy on student achievement.

The findings in this study are in line with the research conducted by Misbah, et. al (2018) on the development of elearning, it can be concluded that the development of schoology-based e-learning on impulse and momentum materials to practice digital literacy is feasible and can be used in learning. This is supported by data (a) the validity of the valid category, namely with an average of 3.94, (b) the practicality of the media in the very practical category, namely with an average of 3.77 , (c) the effectiveness of the media in the medium category, with a test value N-Gain 0.41 .

Dinata (2021) also revealed that students with good digital literacy skills will try to find and select important information and understand, communicate and convey ideas in the digital space. In addition, digital literacy skills will open up opportunities for students to think, communicate and create which ultimately leads to student learning success.

\section{Conclusion Dan Suggestion:- \\ Conclusion:-}

Based on the research, it was found that the variables of the use of e-learning and the level of digital literacy affect student learning outcomes for practicum courses. This means that maximizing the use of e-learning supported by a good literacy level will greatly assist students in improving the learning outcomes of practicum courses which will have an impact on their competence. 


\section{Suggestion:-}

The variable of the use of e-learning as a learning medium and the level of digital literacy is only able to explain $46.6 \%$ of the variables that affect student learning outcomes for practicum courses. While the remaining $53.4 \%$ is explained by other variables that are not included in this study.

So for future research, researchers can use variables that have not been explained to determine their effect on student learning outcomes for practicum courses.

\section{Reference:-}

1. Allen, M., W. (2011). Michael Allen's 2012 e-learning annual. Pfeiffer. ISBN 978-0-470-913826.

2. Amosa, A. A., Ogunlade, O. O., Obielodan, O. O., \& Nasiru, A. A. (2017). Students' Learning autonomy and facilitating conditions on the utilization of blended learning among pre-service teachers in the University of Ilorin. Conference proceeding Association for Innovative Technology in Education (AITIE 2017) (pp. 67-74). Ilorin: Association for Innovative Technology in Education.

3. Chandio, A. R., Haider, Z., Ahmed, S., Ali, M., \& Ameen, I. (2018). E-goverment in Pakistan: Framework of opportunities and challenges. Gsj, 6 (12).

4. Collin, B. \& Moonen, J. (2001). Flexible learning in a digital world: Experiences and expectations. London; Kogan Page.

5. Derbyshire, H. (2003). Gender issues in the use of computers in education in Africa.

6. Dinata, K. B. (2021). Literasi Digital Dalam Pembelajaran Daring. Jurnal Eksponen, Vol. 11, No. 1, 2021.

7. Effendi, F., Bustanur\& Mailani, I. (2019). Pengaruh Literasi Media Digital Terhadap Prestasi Belajar Mahasiswa (Prodi PAI UNIKS). JOM FTK UNIKS, Vol. 1, No.1.

8. Frehywot, S., Vovides, Y., Talib, Z., Mikhail, N., Ross, H., Wohltjen, H., \& Scott, J. (2013). E-learning in medical education in resource constrained low-and middle-income countries. Human resources for health, $11(1), 4$.

9. Gavali, R. (2015). Discovery service for engineering and technology literature through google custom search : A case study. Journal of Library \& Information Technology, vol. 35, no. 6, pp. 417-421.

10. Horton, W \& Horton, K. (2003). E-Learning Tools and Technologies: A Consumer Guide for Trainers, Teachers, Educators, and Instructional Designers. USA: Wiley Publishing, Inc.

11. Isalmiyah, M. \& Widayanti, L. (2016). Efektifitas Pemanfaatan E-Learning Berbasis Website Terhadap Hasil Belajar Mahasiswa STMIK Asia Malang Pada Mata Kuliah Fisika Dasar. Jurnal Ilmiah Teknologi dan Informasia ASIA (JITIKA), Vol. 10, No. 1.

12. La Ucu, N., et. al (2018). Analisa Pemanfaatan E-Learning Untuk Proses Pembelajaran. E-Jurnal Teknik Informatika, Vol. 13, No. 1, ISSN : 230-8364.

13. Misbah, et. al (2018). Pengembangan E-Learning Berbasis Schoology pada Materi Impuls dan Momentum untuk Melatihkan Literasi Digital. Pancasakti Science Education Journal (PSEJ), Vol. 3, No. 2, Oktober 2018, ISSN : 2528-6714, e-ISSN : 2541-0628.

14. Munir. (2009). Pembelajaran Jarak Jauh Berbasis Teknologi Informasi dan Komunikasi. Bandung: Alfabeta

15. Murtiyasa, B. (2006). Pemanfaatan Teknologi Informasi dan Komunikasi untuk Meningkatkan Kualitas Pembelajaran Matematika, Pidato Pengukuhan Guru Besar Pendidikan Matematika, 19 September 2006, Surakarta: Universitas Muhammadiyah Surakarta.

16. Pusjiastutik, H. (2019). Efektivitas Penggunaan Media Pembelajaran E-Learning Berbasis Web Pada Mata Kuliah Belajar Pembelajaran I Terhadap Hasil Belajar Mahasiswa. Jurnal Teladan, Vol. 4, No. 1, Mei 2019, pISSN : 2527-3191, e-ISSN : 2622-9927

17. Roy, A., \& Raymond, L. (2005). e-Learning in support of SMEs: Pipe dream or reality. Proceedings of $5^{\text {th }}$ European Conference on E-Learning (pp. 283).

18. Sianturi, S.R \& Lisum, K (2018). Peningkatan Motivasi Belajar melalui Evaluasi E-Learning pada Institusi Keperawatan di Jakarta dan Depok. Jurnal Pendidikan Keperawatan Indonesia, Vol. 4, No. 2, 31 Desember 2018, e-ISSN : 2477-3743, p-ISSN : 2541-0024.

19. Suharyanto \& Mailangkay, A.B.L (2016). Penerapan E-Learning Sebagai Alat Bantu Mengajar Dalam Dunia Pendidikan. Jurnal Ilmiah Widya, Vol. 3, Nomor 4, Agustus-Desember 2016.

20. Sulzby,E. \& Teale, W. (1986). Emergent Literacy: Writing and Reading. Norwood. Ablex Publisihing Corporation 
21. Suwastika (2018). Pengaruh E-Learning Sebagai Salah Satu Media Pembelajaran Berbasis Teknologi Informasi Terhadap Motivas Belajar Mahasiswa. Jurnal Sistem dan Informatika, Vol. 13, No. 1, November 2018, p-ISSN : 1858-473X, e-ISSN : 2460-3732.

22. Vitoria, L., Mislinawati, M., \& Nurmasyitah, N. (2018, September). Students perceptions on the implementation of e-learning: Helpful or unhelpful?. In Journal of Physics: Converence Series (Vol. 1088 , No. 1, p. 012058). IOP Publishing.

23. Wima, P. \& Lawler, M. (2014). Investing in ICTs in educational institutions in developing countries: An evaluation of their impact in Kenya. International Journal of Education and Development Using ICT. Available http://ijedict.dec.uwi.edu?viewarticle.php?id=241.

24. Yusuf, M., O. (2005). Information and communication technology and education: analyzing the Nigerian national policy for information technology. International Education Journal, vol. 6, no. 3, pp. 316-321. 